Socialist Studies: the Journal of the Society for Socialist Studies 5(2) Fall 2009: 1-16

Copyright (C) 2009 The Author(s)

EDITORIAL

\title{
What is Socialism? What are Socialist Studies?
}

\author{
ELAINE COBURN \\ Co-Editor, Socialist Studies: the Journal for the Society of Socialist Studies \\ Centre d'analyse et d'intervention sociologiques (CADIS)-Ecole des Hautes Etudes en \\ Sciences Sociales, Paris, France \\ Keywords \\ - Socialism • Socialist Studies • Democracy • Capitalism • Marx \\ Mots clés \\ - Socialisme • études socialistes $\bullet$ démocratie $\bullet$ capitalisme $\bullet$ Marx
}

There is no single answer to the question: 'What is socialism?' At the very least, socialism is at once a critical theory of capitalism and an aspiration for a more socially just and democratic society beyond capitalism. G.A Cohen (2009) might have said that socialism is like a camping trip, in which activities are carried out both cooperatively and independently, partly according to ability and predilection, in a context in which sharing seems natural. Utopian socialists, as they were called by Marx and Engels (1985), might argue that socialism is about the creation of model communities based on values of solidarity and equality within capitalism. The former communist countries claimed to be examples of actuallyexisting socialism within a capitalist world system, an argument that socialists must take seriously.

Clearly, given the broadness of the debate, the answer sketched out below to the question, 'What is socialism?' is a partial, particular vision. Insights are drawn mainly from Marx, rather than other socialist thinkers but this is not an attempt to interpret Marx's vision of socialism. Rather, it is an open exploration, informed by a sociological outlook, of what socialism might mean in contemporary times.

The general argument runs as follows. Socialism seeks to create a truly democratic society by extending the principle of democratic debate to the economic as well as the formal political sphere. As a critical theory, socialism is founded on a critique of the class inequalities fundamental to the existing capitalist mode of production and characteristic of previous modes of production. These inequalities are incompatible with genuine democracy. Socialism has organic links with other social movements with 
Socialist Studies: the Journal of the Society for Socialist Studies 5(2) Fall 2009: 1-16

liberatory impulses, from radical feminism to the disabled movement, insofar as these strive for real equality, necessary to true democratic decision-making. Finally, socialism is an ideological as well as material project, concerned with freeing the human imagination to think of new, more just ways of organizing our profoundly social lives.

In the second half, the question 'What is socialist studies'? is explored. Following from the above, it is argued that socialist studies are a critical analytical approach that understands the world capitalist political economy as the context for contemporary social relationships. Yet, capitalism is not static, but has undergone several historical transformations and exists in somewhat different forms across the world system. Socialist studies seek to understand these historical transformations and different types of contemporary capitalism, offering insights into its characteristics functions and dysfunctions or 'contradictions' as well as its effects on human welfare. This includes analysis of how class-based oppressions are historically linked with other forms of oppression, for example, based on race or gender. Finally, in examining the contradictions of capitalism, socialist studies consider capitalism's faultlines and contradictions. In so doing, the aim is not to discern the automatic unfolding of History but rather to understand spaces for political struggle that challenge capitalism, portending a world beyond existing capitalist relationships.

In a world of stark inequalities, socialism and socialist studies matter, both as a critical theory of capitalism and as an aspiration for a more just organization of human relationships. Socialism and socialist studies may not have all the answers, but they are an important, necessary part of the debates about the kind of world in which we would like to live, one in which healthy, creative lives are no longer the privilege of the few but the experience of all.

\section{Socialism as Democracy and as Critique of Capitalism}

Socialism seeks to transcend capitalism to create a thoroughly democratic society. This means ending capitalist relations based on an exploitative class relationship between the capitalist and working class. Democratic decision-making is extended to the economic sphere. The ways that human beings get together to create what they need to live, food, clothing, shelter and so on, becomes the subject of conscious collective discussion and debate. In socialism, the mode of production is no longer the more or less visible determinant of basic social chances, like the likelihood of living or 
dying in the first year of life. Instead, the mode of production becomes the social product of democratic decisionmaking.

Historically, socialism can be understood as a response to the incomplete liberal revolution against feudalism, with its naturalized inequalities and servitude, based on the idea that some are born better than others. Indeed, one of Marx's basic messages is that the liberal revolution did not go far enough, prisoner of its own contradictions. Thus, with liberals, Marx calls for freedom and equality, both essential to democracy. Against liberals, he argues that capitalist market relationships are fundamentally incompatible with real freedom and equality - and so genuine democracy.

The critical argument against capitalism is familiar. Marx asks what real freedom exists for the billions of workers who spend the better part of their waking hours 'chained to the machine', stunted physically, mentally and emotionally by mindnumbing labour. In the contemporary capitalist world, despite all the talk about the 'virtual' economy, millions in both the developed and developing world are chained to the machine, in sweatshops and assembly lines of the kind that were familiar to Marx and Engels in 19th century England (Huws 1999). Many other working people carry out service activities of daily mindnumbing drudgery, from telephone sales to caring activities that in other contexts may be difficult but rewarding. Lives are not free in any meaningful sense when they are spent tending the machine or offering services at an inhuman pace and in circumstances that degrade both the service giver and receiver. Nor is it reasonable to talk about freedom when there is no alternative to participation in the market nexus. For many 'choice' is reduced to earning a wage in work that may be monotonous, degrading or dangerous; the alternative is a life of penury.

At the same time, socialists reject liberal visions of freedom, particularly the impoverished vision of freedom that develops in market societies. Of course, freedom to choose matters, not least in the realm of formal politics. Clearly, formal political choice in regularly held, fair elections every few years is an improvement on the inherited political power wielded by feudal lords and kings. Movements across the world against dictatorships are a reminder, if one is needed, of the importance of many formal political liberties. The millions of workers who participated in the Solidarity movement in Poland, eventually leading to the fall of the officially Communist Soviet regime there and contributing to the collapse of the Soviet Union generally, struggled for a wide range of basic political freedoms, from the right to form legally-recognized unions to the right to 
Socialist Studies: the Journal of the Society for Socialist Studies 5(2) Fall 2009: 1-16

present candidates in state elections. These rights and freedoms are not trivial and the exercise of formal national and sub-national politics still matters. Indeed, the role of the Co-operative Commonwealth Federation (CCF), now New Democratic Party (NDP) in introducing universal health care in Canada during the CCF's decades in power in post-war Saskatchewan, is just one important reminder of the ways that formal politics can result in major, if reversible working class gains.

Yet, socialists maintain that such formal political freedoms do not go far enough, both substantively and in terms of scope. Substantively, for many, formal political freedoms centre on the right to vote once every several years, often for a narrow range of political choices. Voting rates around $50 \%$ are common in many western developed nations, symptomatic of the disillusionment with formal, representative politics. Rights to present candidates and form unions are critical, but their translation into genuine political power is often frustrated for the working class relative to the bourgeoisie, in a context in which many fundamental questions are defined as 'extra-political'. Indeed, the scope of liberal political freedoms is defined to exclude whole areas of social life. Notably, they do not extend to the workplace, for example, where 'the market decides'. The distribution of goods, services and wealth are not a matter for democratic debate. Profits, for example, automatically accrue to capitalist owners of the means of production, rather than workers. Thus, the liberal vision of freedom, especially political freedom, is limited and contradictory, excluding vast areas of social life and ignoring the ways in which class inequalities (about which more below) translate into the unequal exercise of formal political freedoms.

Moreover, in market societies, this original liberal vision of freedom is frequently lost. In everyday life, freedom comes to mean little more the ability to 'choose' between different commodified goods and services. In the heart of market fundamentalism, in much of the United States, freedom is literally equated with market relationships. Thus, for example, in the current debate on extending public healthcare, freedom is equated with the citizen-as-consumer's right to pay for privatized healthcare, even if this means that a substantial minority goes without any healthcare at all. The identification of freedom with market relationships is so strong that many Americans are literally protesting for their right to pay for the ambulance that takes them to a hospital in an emergency - this would merely be an absurd spectacle, if it didn't have tragic consequences for so many. Indeed, for many Americans, 'freedom' to choose to pay for health care means compulsory attendance at free 'charitable' clinics or going without any 
treatment. Consumer 'freedom' is directly proportionate to ability to pay. And of course, this impoverished vision of consumerism as freedom is unavailable to the world's vast majority, as the recurrent crises of underconsumption recall.

For socialists, as for liberals, freedom is an important value. But, for socialists, freedom means the ability to opt out of paid, formalized work, not least work that is degrading and dangerous, with the possibility of maintaining a decent life. Genuine freedom first means freedom from want. More broadly, for socialists, it is obvious that political freedom, the liberal 'freedom to choose', must be extended beyond the formal political to the economic realm. This includes the free exercise of the individual and collective will in deciding how work is organized and how goods and services will be shared. None of this is possible under capitalism, which, moreover, has a tendency to reduce the original liberal celebration of freedom to little more than consumer choice, a privilege based on the ability to pay.

Relatedly, and in addition to rejecting liberal visions of freedom, Marx rejects liberal claims that genuine equality is possible within capitalism. In liberal capitalism, human beings are formally equal, a value commitment legally asserted in international charters like the United Nations Declaration of Human Rights. Clearly, this is progress over assertions of natural inequality among human beings. However, such formal declarations of equality are systematically undermined by the normal workings of the class-based capitalist system. Class inequalities inevitably translate into systematic class-based divergences in the advantages enjoyed across all spheres of life. The bourgeois and the working class, the rich and the poor across the capitalist world system, have unequal access to social goods, like health and education, and unequal exposure to social risks, including violence, the effects of environmental disasters and so on. In a world in which a few are billionaires and over a billion other human beings are starving, declarations of equality are purely formal and aspirational, entirely at odds with grotesque material inequalities.

In the political realm, as in other spheres of social life, capitalism skews the field of class struggle, so that the bourgeois have greater political weight than the working class. The relative dominance of the bourgeoisie is exercised in all sorts of ways, many mundane and direct. For example, corporate and private donations ensure that most political parties are captured by bourgeois interests, granting them a significant edge in resources for organizing and advertising over genuinely working class 
Socialist Studies: the Journal of the Society for Socialist Studies 5(2) Fall 2009: 1-16

parties. More fundamentally, bourgeois interests are served because they are able to propagate ideologies that present capitalism as natural, inevitable and 'in the general interest' (Marx 1978a), whilst excluding ideas that emphasize capitalism's social, therefore changeable nature and that ways that capitalism serves a minority bourgeois rather than majority working class interest. Indeed, bourgeois control over the means of mental production, over the ideological apparatus, notably including the mainstream for-profit media, means that anti-capitalist ideas are literally unthinkable for many, outside the realm of 'commonsense' and rationality (Gramsci 1971). Together with other ideological apparatus, from educational manuals to street and building names that celebrate capitalist entrepreneurial 'donors' but ignore the working class hands that built them, capitalism becomes an inevitability beyond political debate. Material inequalities translate into inequalities in the realm of ideas, with bourgeois interests prevailing over working class interests.

Ultimately, Marx rejects liberal, capitalist notions of equality. Equality of opportunity is a chimera, because class, but also gender, race, disability and other factors, which are not chosen, profoundly affect the life course under capitalism. Similarly, Marx rejects equality of outcome. Equality of outcome is not desirable, at least in the simple-minded sense of everyone having equal access to the same goods, broadly defined. Rather, the Marxist notion of equality is summed up in the famous phrase, 'From each according to his ability, to each according to his need' (Marx 1978b), a notion of justice and rights that depends upon the full expression of individual capacities and attention to differential human needs. How such a vision of equality might play out is obvious in many common situations. For example, a student who excels at school and is comfortable in the school environment does not the same support as a student who struggles at school. Justice does not depend upon treating these students equally, but paying attention to the specific capacities and needs of each, including more support for the struggling student.

Moreover, in actually-existing market societies, inequality is championed more often than equality. Naturalized inequalities supposedly relate to individual, entrepreneurial initiative and merit. Class inequalities are seen as functional, assigning the most talented individuals to the most important social roles. At the same time, the poor are despised for their poverty, often taking forms of mean-ness that fuse class, racial and gender hatreds, summed up in shorthand terms like 'the welfare queen', the 'chav', 'white trash' and so on (Tyler 2008). The working class are blamed for their plight, including in social theories that explain inequalities as a 
consequence of a 'culture of poverty' rather than as the expression of inherited class privilege and what might be termed a 'culture of tolerance' for inequality (Crutchfield and Pettinicchio 2009). Liberal ideas about equality are perverted within market society, so that ultimately it is inequality that is rationalized. The incredible wastefulness of capitalism, which resigns billions - with all their capacities and talents -- to misery, is obscured by rhetoric celebrating individual achievement. In place of such market rationalizations, socialists emphasize the importance of solidarity.

In sum, Marx maintains that the liberal revolution did not go far enough. In overthrowing the naturalized, rigid god-given inequalities of the feudal mode of production, the capitalist mode of production generates new, naturalized inequalities, supposedly related to individual entreprenurial initiative and merit. In fact, such inequalities are the consequence of the domination of the working class by the capitalist class, in the workplace, in the formal political realm and across social life generally. Insofar as capitalism is characterized by an absence of real freedom and real equality, it is inevitably fundamentally undemocratic, generating a bourgeois political system as opposed to an authentically democratic one. Finally, without a strong democratic voice, the terrible fate of the humanity's majority will continue unheard, as the wants of the wealthy win out in an unequal political field over the fundamental needs of the poor (Coburn and Coburn 2007, 26).

Socialism is not simply a critique of capitalism, but an argument for a world governed by different social relationships and different values than those that prevail in market societies. Socialists argue that genuine freedom and choice can only begin when there is freedom from want. Formal declarations of equality, including in the political sphere, is only possible in the context of material equality, in the sense of having needs met. Celebrations of individual talents are only meaningful in a context of solidarity, in which socially generated wealth is shared so that the capacities of all may be expressed. Democratic decision-making cannot be constrained to the narrow, formal political sphere. Rather, democratic decision-making must be extended to all areas of social life, including the workplace and the economy generally. Ultimately, ensuring the conditions for true liberty, true equality and genuine democracy depends upon revolutionizing the fundamentally unequal class relationships that characterize capitalism. In a classless society, history would begin, in the sense that for the first time human beings would self-consciously organize to decide how to produce and share the goods and services needed in order to live. Rather than an inherited 'nightmare' weighing upon social 
Socialist Studies: the Journal of the Society for Socialist Studies 5(2) Fall 2009: 1-16

relationships, the mode of production is for the first time the product of reflexive, democratic decision-making.

\section{What are Socialist Studies?}

Socialist studies are critical reflections about the workings of the capitalist mode of production. Theoretically, such analyses privilege an understanding of class relationships, and the ways that class struggles have shaped capitalism over time and across different national types of capitalism. This means that socialist studies reach back to explain the different phases of capitalism, from its beginnings five hundred years ago (Wallerstein 1976), when what would now be called transnational corporations set forth, with state support, from the imperial centres to conquer 'new' territories, murdering indigenous peoples to gain access to resources or forcibly assimilating indigenous peoples into market relationships with distant colonial centres. At the same time, socialist studies seek to understand the different forms of capitalist relationships across different national contexts. The neoliberal Anglophone states, for example, contrast in important ways with Scandinavian welfare states, which, although increasingly market-oriented, still have more extensively decommodified social relationships than in many other nations. There are ideological differences across national states, too, reflected in the different understandings of what constitutes 'common sense' and the limits of public debate. In North America, being called a socialist or communist is enough to disqualify an individual from legitimate political debate, while in France and other contexts, socialists and communists participate regularly and respectably - if still at the margins - of public debates, including in the mainstream, for-profit media.

Understanding capitalism's different forms means analysing the balance of class forces or the state of political struggle at any historically specific moment. Moments of crisis may be particularly important, marking moments of struggle that result in a new balance of class forces. For example, it is impossible to understand the emergence and worldwide diffusion of the contemporary neoliberal regime without recognizing the ways in which the 1970s economic crisis undermined the post-war Keynesian consensus in the developed world. This created an uncertain policy environment that an emerging transnational capitalist class was able to exploit, as newly mobile capital credibly threatened both states and the working class with capital flight in order to make relative political gains at the expense of the working class (Ross and Trachte 1990). 
In particular, the relative increase in the strength of transnational capital vis-à-vis the working class translated into the extension of market relationships, through a now-familiar bundle of policies: the privatization of goods and services, the commodification of the former global commons, including living organisms, and the liberalization of financial capital. These processes of market expansion were developed alongside an authoritarian, penal state disciplining segments of the working class domestically, while military interventions sought to protect domestic capital and secure resources for domestic capital abroad. During the same period, in the developing world, the neoliberal consensus reflecting the new relative strength of the capitalist class was often imposed via institutions like the World Bank and International Monetary Fund. Mainstream economists, the ideologues of capitalism, rationalized the extension of capitalist markets via these institutions as non-political 'technical' interventions. The collapse of the Soviet Union was said to herald the 'end of History' (Fukuyama 1992), and the final triumph of liberal capitalism as the ultimate horizon for all possible political economies.

In this way, socialist studies seek to understand transformations within capitalism, as a consequence of the changing balance of class forces. This means recognizing the ways in which material changes, including cyclical crises of capitalism, are linked with ideological transformations and new hegemonic justifications for specific market forms.

In addition to analysing the state of class struggle in any particular historical moment or national context, socialist studies seek to describe and explain the ways in which capitalism has been articulated with other forms of social oppression. Although the specific contribution of Marxism is an emphasis on unequal class relationships, as the defining feature of capitalism, feminist scholars and scholars of colour have emphasized the ways in which early and contemporary capitalist expansion depends upon racist and sexist ideologies. Thus, it is impossible to understand early imperialist forms of capitalism without recognizing the ways in which racist ideologies justified the murder or forced assimilation of indigenous people whose existence threatened to block the appropriation of 'new world' resources and whose traditional ways of life challenged the spread of market relationships. Today, racist ideologies continue to be useful to the capitalist class, insofar as divisions among racialized workers fracture potential working class solidarity. Indeed, postmodern identity politics are arguably an expression of the 'cultural logic of late capitalism', in which fragmented national, racial, sexual and other identities are celebrated 
Socialist Studies: the Journal of the Society for Socialist Studies 5(2) Fall 2009: 1-16

specifically at the expense of class based politics, rather than being articulated with them (Carroll 2006, 12).

Likewise, socialist studies now grapple with the ways that capitalism is articulated with gender inequality. Women's reproductive labour, including housework, childrearing, eldercare and other work, whether paid or unpaid, is necessary to maintain both working class and bourgeois households. At the same time, women's role in reproductive labour frees men to participate in other activities outside of the home, including union organizing for working class men. Within the contemporary working class, paid work is still sharply gendered. Indeed, some have argued that a typical feature of migrant labour in neoliberal capitalism is 'women in services', including sex work or prostitution, with 'men in arms' (Falquet 2006), employed in private security and military services. Socialist studies cannot pretend to understand actually-existing capitalism without analysing the ways in which class relationships are historically intertwined with gender inequalities over time and across different national contexts.

Of course, socialist studies have not always addressed insights by feminists, anti-racist scholars and other progressive traditions, including ecological arguments. Rather, struggles by women, people of colour, environmental activists and so on, obliged socialists to take into account these aspects of actually-existing capitalisms neglected in 'mainstream' socialism. At the same time, socialist studies do not simply adopt feminist or anti-racist approaches to understanding social relationships. Rather, they are critical of such studies insofar as they specifically overlook dimensions of class inequality. Socialist feminism, for example, rejects the idea that there is a single, unified category of 'women.' Lucy Neville Rolfe, an executive with Tesco, the British-based grocery store and the world's third largest retailer, may share the social attribution of 'woman' with the mainly black South African women fruitpickers that supply Tesco (Smithers and Smith 2009). But their interests are opposed, since higher wages for the South African women means lower profits for Tesco. Furthermore, Rolfe-Neville has a broad structural interest in supporting a capitalist system that justifies the expropriation of these women's labour as profit for Tesco in the first place. Women do not share a common fate within the world capitalist system and the political implication is that women's solidarity cannot extend, except in a temporary strategic way, across class lines. A perfectly gender-blind capitalist society would still leave the vast majority of women in the working class, sharing the unequal fate of working class men compared to their bourgeois counterparts. 
Socialist studies insist that women's liberation, like the liberation of racialized minorities, will only be meaningful for all women when unequal class relationships are ended as well as gender inequalities. A similar approach informs socialist appreciations of anti-racist scholarship.

Socialist studies have a particular responsibility to study the socalled Communist nations, including the former Soviet Empire and dictatorships like that in Romania under Ceaucsescu. These have to be taken seriously as studies in actually-existing socialism, in the same way that actually-existing capitalism, with all its contradictions and excesses, cannot simply be ignored by free-market ideologues who insist that cyclical crisis and persistent poverty would not be characteristic of a pure market society e.g., one without 'residual' state interference. The horrors committed by the Communist dictatorships, their characteristic lack of basic, formal political freedoms, may be the antithesis of socialist aspirations, grounded in the pursuit of genuine freedom, real equality and meaningful democracy. But, any critical, reflexive socialist analysis must confront these regimes' claims to be socialist and consider the lessons for socialist political struggle. Characteristic of this necessary intellectual honesty, for example, is Einstein's warning, in his article, 'Why Socialism?' (1949) about the anti-democratic tendencies inherent in 'technocratic' centralized planning. This theme would be taken up more directly by Foucault (not, of course, a socialist scholar) but represents one argument that must surely be considered by any socialist in the post-Soviet era.

Socialist studies are wide-ranging. Insofar as the world capitalist system has been the context for social relationships for hundreds of years, socialist studies have distinctive, class-based insights to bring to the study of most social phenomena. Few realms, if any, maintain total autonomy from the capitalist system. Indeed, even radical utopians who decide to live entirely 'apart from' market relationships are marked by the capitalist system, beginning with their own inevitable marginality. Thus, socialist studies address every topic, more or less obviously linked with analyses of the world capitalist political economy: environmental questions, the ways in which class is reproduced in styles of dress and speech, the contradictions of formal anti-racism in the Soviet Union (Roman 2007), the ways in which physician-patient interactions and forms of 'consent' reproduce liberal models of deracinated individuals that do not take into account the ways that individuals are socially embedded, including in unequal class but also cross-cultural relationships (Kaufert and O'Neill 1998), and so on. In addition, socialists consider every aspect of research, so that research 'methods' are recognized not simply as technical tools for 
Socialist Studies: the Journal of the Society for Socialist Studies 5(2) Fall 2009: 1-16

discovering truths about the capitalist political economy but as deeply implicated in political relationships, not least between the researcher and those studied. Whether or not Tuhiwai Smith (2004) is identified as a socialist scholar, her lessons about the ways in which researchers are implicated in the colonial project - 'they came, they named, they claimed' are clearly salient for socialists researchers concerned both to analyse how research is shaped by the capitalist (imperialist) context and how it might be better oriented to serve liberatory political struggles against capitalism.

In the same vein, socialist studies analyse the contradictions of capitalism, not least since such contradictions are the places where spaces open up for progressive struggle both for reforms within capitalism and for transformations beyond capitalism. One reason for seeking to describe and explain the differences between Scandinavian and Anglo-saxon welfare states, for example, is to understand how decommodified spaces can be constructed within capitalist states. Thus, Scandinavian welfare states offer more opportunities for women and men to achieve a better life-work balance than many Anglosaxon welfare states eg., via programmes that enable parents to temporarily opt out of the workforce to look after children. This comparative difference ought to be of interest to socialists pressing for decommodified spaces in all national contexts. If the Communist state of Kerala in India has lower infant mortality rates, better longevity and superior literacy rates compared to most other 'developing' states, despite its relatively meagre resources, than it is important for socialist to understand why, with an aim to improving life conditions here and now. Socialists cannot sacrifice the current generation to a future socialist world, but must be concerned with making life better for as many as possible, right now.

Socialist studies are interested in the limits and possibilities of projects that embody the kind of practices socialism hopes to achieve more broadly: political experiments like the participatory budgets in Porto Alegre, Brazil, open-source software like the kind that hosts Socialist Studies, co-operative societies in Québec, public sector 'social unionism', and the emergence of the 'alter-globalization' movement around events like the World Social Forum, with its counterhegemonic slogan 'Another World Is Possible'. Socialist studies analyse such dynamics, to understand how working class solidarity may be fostered and capitalism challenged, as well as the ways that such projects may be captured or sometimes, perhaps usually, defeated by a world capitalist system that has shown tremendous resiliency and flexibility over its centuries-old existence. Recognizing the ways that, for example, environmental impulses are translated into a 
shallow 'green consumerism' is not simply a defeatist message for socialist struggles, but a call for environmentalism to be linked more durably to a critique of market relationships (Carroll 2006). In sum, socialist studies critically analyse what Harvey (2000) has called the 'spaces of hope' within capitalism.

\section{The Future of Socialism and Socialist Studies}

Socialism is both a critical tool, a class-based analysis of the world capitalist system that has been the context of human lives for centuries, and an aspiration for a more just equal world in which human needs are met and the creative capacities of all may be expressed and shared. Socialist studies are an ambitious field of theoretical reflection and research, seeking to understand all aspects of contemporary social life, including the research process itself, and the ways in which these are shaped by an unequal class system. At the same time, socialist studies analyse how class oppressions are articulated with other oppressions, notably gender and race inequalities, but indeed, any source of oppression that limits the full participation of any human being. Thus, for example, disabled activism that articulates the ways in which needs of the diverse disabled population may be better accommodated, matters to a socialism that envisions equality in terms of 'from each according to his ability, to each according to his needs'. Socialist studies emphasize the ways in which disability can be understood through the lens of class analysis, describing and explaining the interactions between disability and class location and more broadly the ways in which market societies devalue disabled populations whose needs cannot be met through market signals that see disability accommodation, first and foremost, as cost. In this sense, socialist studies are omnivorous, interested in all aspects of social life within an analytical framework that stresses the role of capitalism and unequal class relationships. In addition, socialist studies are concerned with the emergent possibilities for different social relationships that are evident in political struggles by the working class and other progressive movements: struggles organized around commitments to genuine equality, freedom and democracy within a society that emphasizes solidarity as much as individual self-expression.

Today's world is one in which the contradictions of capitalism, its abject failure to live up to its original liberal promises of equality and freedom, are arguably more obvious than at any time in history. We live in time of immense wealth and terrible misery. Inequalities are greater than 
Socialist Studies: the Journal of the Society for Socialist Studies 5(2) Fall 2009: 1-16

they have ever been. A tiny minority have so much wealth that it is no longer connected in any way to needs or even wants. Rather, this wealth is an expression of money fetishism that is at once irrational and inevitably connected with the exercise of power, the will of the few prevailing over the interests of the many. Yet, despite this enormous wealth, over one billion human beings, one sixth of humanity, do not have enough to eat (United Nations 2009). This grotesque situation is the consequence of five hundred years of capitalism, which is capable of producing more goods than at any other time in human history but incapable of ensuring even basic subsistence to masses of human beings.

The current economic crisis has forced attention to the failings and contradictions of the latest, neoliberal phase of capitalism, making them starker. Even in the heart of market fundamentalism, in the declining hegemonic power of the United States, it is apparent that business simply cannot continue 'as usual'. The crisis of underconsumption, in a world where more goods than ever are produced, is grossly perverse and unacceptable. Ephemeral products that, in many cases, no one really wants and that are made at the cost of tremendous human suffering and environmental devastation, are churned out. Meanwhile, many go with basic needs unmet. Human values and social life are deformed in a world in which the only value that matters is exchange-value. In such a world, should it be surprising that even children and human organs may be bought and sold, despite formal commitments to the contrary? Liberal commitments to equality and freedom are inevitably starkly contradicted by the normal functioning of markets, that systematically undercut such formal rights in order to privilege profit creation.

Socialism may not answer all the problems within capitalism. But, with its sustained critique of unequal class relationships that characterize the world capitalist political economy, it is a beginning. Socialism challenges capitalist 'common sense', confronting capitalism with its own contradictions and the unacceptable human cost of its everyday functions. At the same time, socialism offers more or less radical alternative visions for human social relationships, based on putting human needs first and privileging solidarity as the precondition for real equality, freedom and democracy. Ultimately, socialism confronts humanity with its own responsibility, insisting that human life is profoundly social. No set of social arrangements is permanent, a given that cannot be changed. Rather, it is up to us, collectively to decide what kind of world in which we want to live. 


\section{References}

Carroll, William K. 2006. “Hegemony, Counter-Hegemony, Anti-Hegemony.” Socialist Studies 2, no. 2: 9-43.

Coburn, David and Coburn, Elaine S. 2007. "Health and Health Inequalities in a Neo-Liberal World." In The Economics of Health Equity. Edited by Di Mc Intyre and Gavin Mooney. Cambridge: Cambridge University Press.

Cohen, G.A. 2009. Why Not Socialism? Princeton: Princeton University Press.

Crutchfield, Robert and Pettinicchio, David. 2009. "Cultures of Inequality: Ethnicity, Immigration, Social Welfare and Imprisonment." The Annals of the American Academy 623, no. 1: 134-147

Einstein, Albert. 1949. "Why Socialism?" Monthly Review 1. Available at: http://www.monthlyreview.org/598einstein.php

Falquet, Jules. 2006."Hommes en armes et femmes 'de services': tendances néolibérales dans l'évolution de la division sexuelle et internationale du travail." Cahiers $d u$ genre 40: 15-37.

Fukuyama, Francis. 1992. The End of History and the Last Man. New York: Avon Books.

Gramsci, Antonio. 1971. Selections from the Prison Notebooks. New York: International Publishers.

Harvey, David. 2000. Spaces of Hope. Berkeley: University of California Press.

Huws, Ursula. 1999. "The Myth of the Weightless Economy.” Socialist Register 35: 29-55

Kaufert, Joseph and O’Neill. 1998. “Culture, Power and Informed Consent: The Impact of Aboriginal Health Interpreters on Decision-Making." In Health in Canadian Society. Third Edition. Edited by David Coburn, Carl D'arcy and George Torrance. Toronto: University of Toronto Press: 131-146.

Marx, Karl. 1978a. "The Ruling Class and the Ruling Ideas.” In The Marx-Engels Reader. Second edition. Edited by Robert C. Tucker. London: W.W. Norton and Company: 172-175.

Marx, Karl. 1978b. Critique of the Gotha Programme. Moscow: Progress Publishers.

Marx, Karl and Friedrich Engels. 1985. The Communist Manifesto. London: Penguin Classics.

Roman, Meredith. 2007. "Racism in a 'Raceless' Society: The Soviet Press and Representations of American Racial Violence in Stalingrad in 1930." International Labour and Working Class History 71:185-203.

Ross, Robert and Kent C. Trachte. 1990. Global Capitalism: The New Leviathan. Albany: State University of New York Press.

Smithers, Rebecca and David Smith. 2009. "Tesco 'breaking promise' to South African fruitpickers." The Guardian. Available at: http://www.guardian.co.uk/business/2009/may/15/tesco-south-africaworkers-conditions.

Tuhiwai Smith, Linda. 2004. "Research Adventures on Indigenous Lands.” In Decolonizing Methodologies: Research and Indigenous Peoples, Linda Tuhiwai Smith, 78-94. London: Zed Books. 
Socialist Studies: the Journal of the Society for Socialist Studies 5(2) Fall 2009: 1-16

Tyler, Imogen. 2008. "Chav Mum Chav Scum: Class Disgust in Contemporary Britain." Feminist Media Studies 8, no 1: 17-34.

United Nations, Food and Agriculture Organization. 2009. The State of Food Insecurity in the World 2009: Economic Crises - Impacts and Lessons Learned. Rome: Food and Agriculture Organization.

Wallerstein, Immanuel. 1976. The Modern World-System: Capitalist Agriculture and the Origins of the European World-Economy in the Sixteenth Century. New York: Academic Press. 